\title{
HUBUNGAN PENGETAHUAN DAN STIGMA PADA KELUARGADENGAN BEBAN KELUARGA DALAM MERAWATPASIEN SKIZOFRENIA DI WILAYAH KERJA PUSKESMAS NANGGALO PADANG
}

\author{
Ziqni ilma al wasi ${ }^{1}$, Dewi Eka Putri ${ }^{2}$, Mahathir ${ }^{3}$, Renidayati ${ }^{4}$ \\ Fakultas Keperawatan Universitas Andalas \\ PoltekkesKemenkes \\ *Correspondence author's email:ziqniilma@gmail.com
}

\begin{abstract}
Families have a heavy burden in caring for ODS. Heavy load perceived by the family due to the level of family knowledge and family stigma. This study aims to determine the relationship knowledge and stigma on families with family burdens in caring schizophrenia patient in the working area of Puskesmas Nanggalo Padang. Types of research this is correlation with the approach cross sectional. The population in this study is a family who cares for ODS in the working area of Puskemas Nanggalo Padang and a sample of 87 people taken withPurposive Sampling. Data collection using a questionnaire Family Interview Scale / Stigma Items, questionnaire knowledge, and a questionnaire Zarit Burden Interview (ZBI). Research result It was found that more than half $(59.8 \%)$ of the families experienced a heavy burden, more than half (57.5\%) of families have a lower or higher level of knowledge half (52.9\%) of families experienced high stigma. There is a relationship meaning between the stigma in the family and the family burden $(p=0,000)$. There is no significant relationship between the level of family knowledge with family burden $(p=0.110)$. It is expected that health workers, especially nurses soul in society to provide health education to the community regarding Schizophrenia. So that society no longer gives stigma to families who will make the family embarrassed in caring for ODS.
\end{abstract}

Keywords: Schizophrenia; Family Burden; Family Stigma; Knowledge

\begin{abstract}
Keluarga memiliki beban yang berat dalam merawat orang dengan Skizofrenia.Beban berat yang dirasakan keluarga disebabkan oleh tingkat pengetahuan keluarga dan stigma pada keluarga berupa perasaan dan malu dikucilkan. Penelitian ini bertujuan untuk mengetahui hubungan pengetahuan dan stigma pada keluarga dengan beban keluarga dalam merawat pasien skizofrenia di wilayah kerja Puskesmas Nanggalo Padang. Jenis penelitian ini korelasi dengan pendekatan cross sectional. Populasi pada penelitian ini adalah keluarga yang merawat ODS di wilayah kerja Puskemas Nanggalo Padang dan sampel 87 orang diambil dengan Purposive Sampling. Pengumpulan data menggunakan kuesioner Family Interview Scale / Stigma Items, kuesioner pengetahuan, dan kuesioner Zarit Burden Interview (ZBI). Hasil penelitian didapatkan lebih dari separoh $(59,8 \%)$ keluarga mengalami beban berat, lebih dari separoh $(57,5 \%)$ keluarga memiliki tingkat pengetahuan yang rendah dan lebih dari separoh (52,9\%) keluarga mengalami stigma yang tinggi. Terdapat hubungan yang bermakna antara stigma pada keluarga dengan beban keluarga $(p=0,000)$. Tidak ada hubungan antara tingkat pengetahuan dengan beban keluarga dalam merawat ODS Diharapkan tenaga kesehatan terutama perawat jiwa di masyarakat untuk memberikan pendidikan kesehatan kepada masyarakat mengenai Skizofrenia. Sehingga masyarakat tidak lagi memberikan stigma kepada keluarga yang akan membuat keluarga malu dalam merawat ODS.
\end{abstract}

Kata Kunci : Skizofrenia; Beban Keluarga; Stigma pada keluarga; Pengetahuan 


\section{PENDAHULUAN}

Salah satu gangguan jiwa yang terbanyak di Indonesia adalah skizofrenia. Skizofrenia merupakan kepribadian yang terpecah antara pikiran, perasaan dan perilaku, dalam artian yang dilakukan tidak sesuai dengan pikiran dan perasaan ${ }^{1}$ Skizofrenia merupakan penyakit otak neurobiologis yang berat dan terus menerus. Akibatnya berupa respon yang sangat mengganggu kehidupan individu, keluarga dan masyarakat . $1 \%$ dari populasi penduduk dunia menderita skizofrenia. Berdasarkan data dari World Health Organization. ${ }^{2}$ tercatat bahwa 23 juta jiwa penduduk dunia menderita skizofrenia ${ }^{3}$.Prevalensi skizofrenia di dunia mengalami peningkatan yaitu dari tahun 2016 sebanyak 21 juta jiwa menjadi 23 juta jiwa pada tahun 2018.

Salah satu provinsi di Indonesia yang memiliki prevalensi terbanyak yang mengalami skizofrenia adalah Sumatra Barat. Berdasarkan data Sumatera Barat menempati posisi kesembilan dengan prevalensi skizofrenia sebesar 1,9 permil setelah Nusa Tenggara Timur dengan 2,1 permil ${ }^{4}$. Sedangkan data ${ }^{5}$ Sumatera Barat menepati posisi kedelapan dengan prevalensi 11,8 permil setelah Sulawesi Tengah dengan 11,9 permil. (Riskesdas, 2018).

Kementerian Kesehatan (2021) melaporkan selamat Pandemi Covid 19 tercatat 277 ribu kasus gangguan jiwa di masyarakat hingga Juni 2020.

Menurut ${ }^{6}$ pada Orang Dengan Skizofrenia (ODS) didapatkan dua tanda dan gejala yang khas yakni negatif dan positif. Gejala negatif ditandai dengan pasien sering mengisolasi sosial, apatis, tidak percaya diri dan kurang motivasi dan penurunan kemampuan dalam merawat diri. Sedangkan gejala positif ditandai dengan pasien sulit mengontrol emosi, melakukan tindakan kekerasan, mengalami halusinasi, delusi atau waham ${ }^{1}$.Gejala yang muncul pada ODS menyebabkan klien dianggap sebagai orang aneh dan dianggap lebih negatif dibandingkan dengan gangguan mental lainnya.

Berdasarkan dampak yang ditimbulkan oleh ODS, maka sangat dibutuh peran keluarga dalam merawat ODS, Keluarga berperan penting sebagai pemberi asuhan primer tidak hanya ODS tetapi juga untuk anggota keluarga dari semua usia yang masih bergantung ${ }^{7}$. Kecenderungan dalam pemberian asuhan keperawatan sehingga terjadi peningkatan jumlah pemberi asuhan yang ganda, hal ini akan menjadi beban bagi keluarga dalam merawat ODS.. ${ }^{8}$.Beban keluarga merupakan respon multidimensi dengan penilaian negatif dan stres yang dirasakan akibat merawat seorang individu yang sakit. Beban keluarga merupakan tingkat pengalaman distres keluarga sebagai efek dari kondisi anggota keluarganya, ${ }^{9}$ Menurut ${ }^{10}$, menjelaskan dampak dari beban yang dirasakan keluarga aka mempengaruhi kemampuan keluarga dalam merawat ODS.Terdapat dua faktor yang paling dominan dalam meningkatkan beban yang dirasakan oleh keluarga. menurut ${ }^{11}$,pengetahuan 
dan stigma merupakan faktor yang paling dominan dalam mempengaruhi beban yang dirasakan oleh keluarga.

Studi pendahuluan yang dilakukan di Wilayah Kerja Puskesmas Nanggalo Padang pada keluarga yang merawat ODS yang dilakukan wawancara terpimpin menggunakan google form. Sekitar 8 dari 15 keluarga yang merawat ODS mengatakan bahwa jam istirahat mereka terganggu akibat merawat ODS, 9 dari 15 keluarga yang merawat ODS mengatakan bahwa mereka terbebani secara finansial dalam merawat ODS. sekitar 8 dari 15 mengatakan bahwa ODS merupakan aib bagi keluarga, keluarga juga mengatakan masayarakat sering kali tidak menghargai anggota keluarga yang merawat ODS dan keluarga juga mengatakan kadang masyarakat memperlakukan keluarga secara tidak adil atau diskriminasi. Peneltian bertujuan untuk mengetahui hubungan pengetahuan dan stigma pada keluarga dengan beban keluarga dalam merawat pasienskizofrenia di wilayah kerja Puskesmas Nanggalo Padang

\section{METODE PENELITIAN}

Jenis penelitian ini adalah penelitian kolerasi yang bertujuan untuk mengetahui hubungan antar variabel yang diteliti dengan pendekatan cross sectiona. Teknik pengambilan sampel pada penelitian ini menggunakan teknik Purposive Sampling.Populasi pada penelitian ini adalah keluarga yang merawat ODS di wilayah kerja Puskemas Nanggalo Padang dan sampel 87 orang diambil dengan Purposive Sampling. Menggunakan instrumen penelitian Family Interview dari schedule For Clinical Assessment In Neuro Psychiatry, kuesioner pengetahuan, dan Zarit Burden Interview (ZBI). Analisa data dilakukan secara univariat dan bivariate untuk menganalisis hubungan tingkat pengetahuan dan stigma pada keluarga dengan beban keluarga menggunakan uji chi square..

\section{HASIL PENELITIAN}

\section{Tabel 1 . Distribusi Frekuensi berdasarkan Karakteristik Responden di Wilayah Kerja Puskesmas Nanggalo Kota Padang Tahun 2020}

\begin{tabular}{lcc}
\multicolumn{1}{l}{$(\mathrm{n}=88)$} & & \\
\hline Karakteristik & Frekuensi & Persentase \\
\hline $\begin{array}{l}\text { 1. Umur } \\
\text { a. dewasamuda }\end{array}$ & 23 & 26,4 \\
\hline b. dewasatengah & 65 & 73,6 \\
\hline 2. Jeniskelamin & 24 & 27,6 \\
\hline a. laki-laki & 63 & 72,4 \\
\hline b. Perempuan & & \\
\hline 3. Pendidikan & 52 & 59,8 \\
\hline a. PendidikanRendah & 35 & 40,2 \\
\hline b. Pendidikan Tinggi & &
\end{tabular}

4. pekerjaan 


\begin{tabular}{lcc}
\hline a. bekerja & 34 & 39,1 \\
\hline b. Tidak Bekerja & 53 & 60,9 \\
\hline 5. Hubungan dengan Pasien & & \\
\hline a. Ayah & 24 & 27,6 \\
\hline b. Ibu & 62 & 71,3 \\
\hline c. Anak & 1 & 1,1 \\
\hline $6 . \quad$ PengahasilanKeluarga & 57 & 65,5 \\
\hline a. $<$ UMR & 50 & 34,5 \\
\hline b. $\geq$ UMR & 30 \\
\hline Total & 87 & 100,0 \\
\hline
\end{tabular}

Berdasarkan tabel 1 sebagian besar (73,6\%) responden berada pada kategori umur dewasa Tengah. Sebagian besar (72,4\%) responden berjenis kelamin perempuan. Lebih dari separoh $(59,8 \%)$ responden memiliki tingkat pendidikan rendah. Lebih dari separoh $(60,9 \%)$ responden tidak bekerja. Sebagian besar $(71,3 \%)$ responden adalah ibu pasien, dan penghasilan Responden lebih dari separoh (65,5\%) dibawah UMR.

Tabel 2. Distribusi Frekuensi Responden Berdasarkan Beban Keluarga, Tingkat
$\begin{aligned} & \text { Pengetahuan, dan Stigma Keluarga Di Wilayah Kerja Puskesmas } \\
& \text { Nangggalo Kota Padang Tahun 2020 }\end{aligned}$
\begin{tabular}{lcc}
\hline Karakteristik & Frekuensi & Persentase \\
\hline Beban Keluarga & & \\
\hline a. Beban Berat & 52 & 59,8 \\
\hline b. Beban Ringan & 35 & 40,2 \\
\hline TingakatPengetahuan & & 57,5 \\
\hline a. Rendah & 50 & 42,5 \\
\hline b. Tinggi & 37 & 52,9 \\
\hline Stigma PadaKeluarga & & 47,1 \\
\hline a. Stigma Tinggi & 46 & 100,0 \\
\hline b. Stigma Rendah & 41 & \\
\hline Total & 87 & \\
\hline
\end{tabular}

Berdasarkan tabel 2 lebih dari separoh (59,8\%) responden memiliki beban yang berat dalam merawat ODS di wilayah kerja Puskesmas Nanggalo Kota Padang. Lebih dari separoh $(57,5)$ tingkat pengetahuan responden berada pada kategori rendah di wilayah kerja Puskesmas Nanggalo Kota Padang. Lebih dari separoh (52,9\%) stigma pada keluarga tinggi di wilayah kerja Puskesmas Nanggalo Kota Padang.

Tabel 3. Hubungan Tingkat Pengetahuan Dengan Beban Keluarga Dalam Merawat Pasien Skizofrenia Di Wilayah Kerjapuskesmas Nangggalo Kota Padang Tahun 2020

\begin{tabular}{ccccccccc}
\hline Pengetahuan & \multicolumn{4}{c}{ Beban keluarga } & \multicolumn{2}{c}{ Total } & \multirow{2}{*}{ OR } & $p$-value \\
\cline { 2 - 7 } & \multicolumn{3}{c}{ Berat } & \multicolumn{2}{c}{ Ringan } & & \\
\cline { 2 - 7 } & $\mathrm{f}$ & $\%$ & $\mathrm{f}$ & $\%$ & $\mathrm{f}$ & $\%$ & & \\
\hline Rendah & 34 & 68.0 & 16 & 32,0 & 50 & 100,0 & 2,243 & 0,110 \\
\hline Tinggi & 18 & 48,6 & 19 & 51.4 & 37 & 100,0 & 2,243 & 0,110 \\
\hline Jumlah & 52 & 59,8 & 35 & 40,2 & 87 & 100,0 & & \\
\hline
\end{tabular}


Berdasarkan tabel 3 dapat dilihat hasil hubungan tingkat pengetahuan dengan beban keluarga bahwa dari 87 orang responden, tingkat pengetahuan rendah 34 orang $(68,0 \%)$ dengan beban keluarga yang berat. Sementara tingkat pengetahuan tinggi 18 orang $(48,6 \%)$ dengan beban keluarga berat. Hasil uji statsitik didapatkan p-value 0,110 artinya tidak ada hubungan antara tingkat pengetahuan dengan beban keluarga dalam merawat ODS. Hasil analisis didapatkan juga $\mathrm{OR}=2,243$ artinya tingkat pengetahuan responden yang rendah mempunyai peluang 2,243 kali untuk mengalami beban keluarga yang berat dalam merawat ODS.

\section{Tabel 4.Hubungan Stigma Pada Keluarga dengan Beban Keluarga dalam merawat Pasien Skizofrenia Di Wilayah KerjaPuskesmas NangggaloKota Padang Tahun 2020}

\begin{tabular}{ccccccccc}
\hline \multirow{2}{*}{ Stigma } & \multicolumn{4}{c}{ Beban keluarga } & \multicolumn{2}{c}{ Total } & \multirow{2}{*}{ OR } & $p$-value \\
\cline { 2 - 6 } & \multicolumn{3}{c}{ Berat } & \multicolumn{2}{c}{ Ringan } & & & \\
\cline { 2 - 7 } & $\mathrm{f}$ & $\%$ & $\mathrm{f}$ & $\%$ & $\mathrm{f}$ & $\%$ & & \\
\hline Tinggi & 38 & 82.6 & 8 & 17,4 & 46 & 100,0 & 9,161 & 0,000 \\
Rendah & 14 & 34,1 & 27 & 65,9 & 41 & 100,0 & & \\
\hline Jumlah & 52 & 59,8 & 35 & 40,2 & 87 & 100,0 & & \\
\hline
\end{tabular}

Berdasarkan tabel 4 dapat dilihat hasil analisis hubungan stigma pada keluarga dengan beban keluarga bahwa dari 87 orang responden, stigma pada keluarga tinggi 38 orang $(82,6 \%)$ dengan beban keluarga yang berat. Sedangkan stigma keluarga yang rendah 14 orang $(34,1 \%)$ dengan beban keluarga yang berat. Hasil uji statsitik didapatkan p-value 0,000 artinya ada hubungan yang bermakna antara stigma pada keluarga dengan beban keluarga dalam merawat ODS. Hasil analisis didapatkan juga $\mathrm{OR}=9,161$ artinya stigma pada keluarga yang tinggi mempunyai peluang 9,161 kali untuk mengalami beban keluarga yang berat dalam merawat ODS.

\section{PEMBAHASAN}

Berdasarkan hasil penelitian yang telah dilakukan pada 87 keluarga yang merawat pasien ODS didapatkan lebih dari separoh $(59,8 \%)$ keluarga yang merawat pasien ODS memiliki beban berat. Hasil penelitian ini sejalan dengan penelitian yang di lakukan oleh ${ }^{12}$ lebih dari separoh $(56,3 \%)$ keluarga memiliki beban keluarga yang berat dalam merawat ODS. hasil penelitian Zahra \& Sutejo, (2019) juga menunjukkan bahwa beban yang dialami keluarga sebagain besar memiliki beban berat $(54,9 \%)$ dalam merawat ODS di poli klinik keperawatan jiwa RSJ Grahasia Provinsi DIY.

Berdasarkan analisis kuesioner yang telah peneliti lakukan di dapatkan 56,9\% keluarga menyatakan kehabisan waktu untuk dirinya karena harus merawat ODS, 44,4\% keluarga menyatakan ODS dapat berpengaruh negatif terhadap hubungannya dengan anggota keluarga lain dan masyarakat, 33,3\% keluarga menyatakan tidak memiliki cukup uang untuk 
merawat ODS, 36,1\% keluarga menyatakan tidak tau harus berbuat apalagi terhadap ODS, dan 37,5\% keluarga menyatakan merasa malu dengan kelakuan ODS. Dimana menurut ${ }^{14}$ dampak dari beban keluarga yaitu keluarga merasa kehabisan waktu untuk dirinya karena harus merawt ODS, dapat berpengaruh negatif terhadap hubungan dengan anggota keluarga lain dan masyarakat, kurangnya finansial keluarga untuk merawat ODS.

Beban yang tinggi dipengaruhi Jenis kelamin, peran keluarga, dan status pendapatan. Pada penelitian ini lebih dari separoh $(72,4 \%)$ keluarga berjenis kelamin perempuan. Hal ini sejalan dengan penelitian Zahra \& Sutejo, 2019 yang menunjukkan bahwa lebih dari separoh $(51,4 \%)$ keluarga berjenis kelamin perempuan. Menurut ${ }^{15}$ wanita memiliki sifat penyayang, penyabar, perhatian dan lebih peka terhadap perasaan orang lain.Beban yang tinggi rata-rata dirasakan oleh keluarga yang perempuan yang berperan sebagai ibu ODS ${ }^{16}$. Sesuai dengan penelitian yang peneliti lakukan dimana sebagian besar $(71,3 \%)$ keluarga yang merawat ODS adalah ibu ODS. Hal ini sejalan dengan penelitian Pérez \& Marqués, (2018) yang menyatakan bahwa sebgaian besar $(78,5 \%)$ keluarga yang merawat ODS berperan sebagai ibu. Tingginya beban yang dirasakan oleh ibu berhubungan dengan fungsi dan peran ibu yang merawat keluarga, dimana ibu harus mengurus rumah tangga, sebagai pengasuh dan pendidik anak-anaknya, dan membantu sosialisasi dalam masyarakat ${ }^{18}$.

Berdasarkan hasil penelitian yang telah dilakukan pada 87 keluarga yang merawat pasien ODS didapatkan lebih dari separoh $(57,5 \%)$ tingkat pengetahuan keluarga berada pada kategori rendah. Hal ini sejalan dengan penelitian Erwanto, (2017) lebih dari separoh $(52,0 \%)$ keluarga memiliki tingkat pengetahuan yang rendah. Penelitian Safitri, (2019) juga menunjukkan bahwa lebih dari separoh $(59,2 \%)$ keluarga memiliki pengetahuan yang rendah. Sri \& Meilina (2016) Pengetahuan keluarga yang rendah akan mempengaruhi pola pikir keluarga.Hasilpenelitian Hal ini sesuai dengan yang dikemukakan oleh Wawan dan Dewi (2011), yang mana faktor-faktor yang mempengaruhi tingkat pengetahuan seseorang adalah pendidikan, pekrjaan, dan umur responden.

Pengatahuan sangat erat hubungannya dengan pendidikan. Dimana dalam penelitian ini lebih dari separoh $(59,8 \%)$ keluarga berpendidikan rendah, hal ini sejalan dengan penelitian ${ }^{20}$ yang menyatakan lebih dari separoh $(53,1 \%)$ berpendidikan rendah. Keluarga yang memiliki tingkat pendidikan yang rendah akan mempengaruhi cara berfikir dan mengolah informasi yang didapatkan termasuk cara merawat ODS ${ }^{21}$. Seseorang yang memiliki pendidikan yang tinggi akan lebih luas pengetahuan yang dimilikinya. Namun tidak menutup kemungkinan bahwa seseorang yang tingkat pengetahuan yang rendah memiliki pengetahuan yang rendah pula, karena pengetahuan tersebut dapat diperoleh dari pendidikan non formal. Selain itu, pengalaman juga dapat menjadi cara menambah sumber pengetahuan ${ }^{22}$. 
Berdasarkan analisis kuesioner yang telah peneliti lakukan di keluarga menyatakan bahwa lebih dari separoh (57,5\%) keluarga tidak mengajak ODS bercakap-cakap saat ODS memperlihatkan tanda kekambuhan, lebih dari separoh $(57,5 \%)$ keluarga menyatakan bahwa tidak mengingatkan ODS untuk minum obat, Lebih dari separoh $(65,5)$ keluarga juga menyatakan bahwa tidak memantau aktivitas yang di lakukan oleh ODS.

Hal ini sejalan dengan Candra \& Kartika, (2019) yang menyatakan bahwa kurangnya pengetahuan keluarga akan membuat anggota keluarga hanya berpendapat bahwa keadaan ODS tidak akan memunculkan risiko yang lebih besar lagi, keluarga tidak menyangka bahwa ODS akan memunculkan tanda-tanda mengalami kekambuhan . berdasarkan uraian diatas peneliti berasumsi bahwa pentingnya bagi keluarga mengetahui tanda-tanda kekambuhan ODS dan pentingnya bagi keluarga selalu mengingatkan ODS untuk tepat waktu dan disiplin dalam mengkonsumsi obat ${ }^{24}$.

Berdasarkan hasil penelitian yang telah dilakukan pada 87 keluarga yang merawat ODS didapatkan lebih dari separoh (52,9\%) keluarga yang merawat ODS memiliki stigma yang tinggi. Hasil penelitian ini sejalan dengan penelitian yang di lakukan oleh ${ }^{20}$ menyatakan lebih dari separoh $(51,0 \%)$ keluarga memiliki stigma yang tinggi. Penelitian ${ }^{25}$ juga menyatakan bahwa lebih dari separoh $(57,4 \%)$ keluarga yang merawat ODS memiliki stigma yang tinggi. Stigma yang tinggi juga akan mengakibatkan keluarga akan merasa tidak nyaman dengan interaksi yang dilakukan sehingga akan berdampak membatasi jaringan sosial individu dengan orang lain, dapat menyebabkan gejala depresi, berkurangnya pendapatan dan juga membuat harga diri rendah pada keluarga ${ }^{26}$.

Berdasarkan analisi kuesioner yang telah peneliti lakukan di keluarga didapatkan bahwa $54,2 \%$ keluarga merasa malu atau dipermalukan dalam merawat ODS, Hal ini sejalan dengan pendapat ${ }^{27}$ yang menyatakan bahwa setiap anggota keluarga yang mengalami rasa malu dalam merawat ODS. Rasa malu tersebut mengakibatkan anggota keluarga menghindari hubungan sosial dengan lingkungan sekitarnya. Berdasarkan hsil uji bivariat didapatkan lebih dari separoh $(68,0 \%)$ keluarga memiliki tingkat pengetahuan yang rendah dengan beban berat. Hasil uji statistik di dapatkan $p$-value 0,110 ( $p$-value > 0,05) berarti tidak ada hubungan yang bermakna antara tingkat pengetahuan keluarga terhadap beban keluarga dalam merawat ODS di wilayah kerja Puskesmas Nanggalo Kota Padang. Namun secara persentase didapatkan bahwa lebih dari separoh $(68,0 \%)$ keluarga yang memiliki beban yang berat memiliki pengetahuan yang rendah.

Hasil penelitian ini didukung oleh penelitian Alfiandi et al., (2018) tentang analisa faktor faktor yang mempengaruhi beban keluarga dalam merawat klien gangguan jiwa di Kabupaten Aceh Besar, didapatkan hasil bahwa tidak ada hubungan antara tingkat pengetahuan keluarga dengan beban keluarga dalam merawat klien gangguan jiwa ( $p$-value 
$>$ 0,05). Berbeda dengan hasil penelitian yang dilakukan Erwanto, (2017) yang menyatakan bahwa terdapat hubungan yang bermakna antara tingkat pengetahuan keluarga dengan beban yang dirasakan keluarga dalam merawat lansia ( $p$-value $<0,05)$.

Menurut asumsi peneliti tidak adanya hubungan anatra tingkat pengetahuan keluarga dengan beban keluarga disebabkan oleh faktor-faktor lain yang mempengaruhi beban keluarga. Faktor lain yang mempengaruhi beban keluarga diantaranya dukungan dari dalam keluarga keluarga yang merawat ODS mendapatkan berbagai macam bentuk dukungan yang berasal dari keluarga besar ODS. Dimana bentuk dukungan keluarga besar yang dimaksud dalam dengan membantu memenuhi kebutuhan dasar pasien, mencari ODS bila hilang atau keluyuran, dan memberi bantuan dana kepada keluarga ( Reknoningsih et al., 2015).

Selain dukungan keluarga ekspresi emosi menjadi faktor lain yang mempengaruhi beban keluarga. Suilia, (2019) menyatakan beberapa penelitian menemukan bahwa ekspresi emosi keluarga yang tinggi rata-rata memiliki beban yang tinggi jika dibandingkan dengan keluarga yang memiliki emosi tinggi jika dibandingkan dengan keluarga yang memiliki emosi yang rendah. Hasil distribusi frekuensi pengetahuan keluarga dalam merawat ODS di dapatkan pengetahuan responden berada pada kategori rendah yaitu 50 orang (57,5\%). Hal ini di dukung oleh penelitian Rahmi, (2018) yang menyatakan bahwa tingkat pengetahuan keluarga terhadap perawatan ODS berada pada kategori rendah. Hasil penelitian didapatkan bahwa sebagian besar anggota keluarga yang berperan sebagai keluarga kurang memiliki pengetahuan yang memadai terkait dengan penyakit dan perawatan ODS.

Berdasarkan hsil uji bivariat didapatkan penelitian dari 87 keluarga yang merawat ODS di dapat sebagian besar $(82,6 \%)$ keluarga memiliki stigma yang tinggi dengan beban yang berat serta kurang dari separoh $(23,8 \%)$ keluarga berada pada kategori beban ringan. Hasil uji statistik dengan Chi-Square di dapatkan $p$-value 0,000 ( $p$-value $<0,05)$ berarti terdapat hubungan yang bermakna antara stigma keluarga terhadap beban keluarga dalam merawat ODS di wilayah kerja Puskesmas Nanggalo Kota Padang.

Puskesmas Nanggalo Kota Padang sebagai salah satu Puskesmas di Kota Padang telah memberikan pelayanan kesehatan jiwa masyarakat dengan berbagai upaya melalui kegiatan promotif dan preventif kesehatan jiwa secara berkala, melakukan deteksi dini gangguan jiwa, home visit, mengadakan pertemuan keluarga dalam upaya peningkatan pemahaman keluarga dalam perawatan pasien gangguan jiwa dirumah dan mencegah kekambuhan sebagai implemenetasi dari Program Indonesia Sehat melalui Pendekatan Keluarga (PISPK). 
Menurut Penelitian ${ }^{32}$ yang menyatakan bahwa keluarga yang memiliki stigma yang tinggi sebanyak $24,7 \%$ dengan beban yang tinggi. Hasil uji statistik Chi-Square di dapatkan $p$-value 0,000 ( $p$-value $<0,05)$ berarti terdapat hubungan yang bermakna antara stigma keluarga terhadap beban keluarga. Hal ini sejalan dengan penelitian yang dilakukan Ayalew et al., (2019) di Ethiopia, menemukan bahwa stigma yang dirasakan keluarga secara positif berhubungan dengan beban keluarga. Hal ini akan berdampak bagi anggota keluarga seperti mengisolasi diri, malu, membatasi diri dalam aktivitas sosial dan menolak untuk berpartisipasi dalam kehidupa normal.

Hasil distribusi frekuensi stigma pada keluarga dalam merawat ODS di dapatkan stigma yang dirasakan keluarga berada pada kategori tinggi yaitu 46 orang $(52,9 \%)$. Hal ini di dukung oleh penelitian Nasriati, (2017) yang menyatakan bahwa lebih dari separoh (52\%) keluarga mengalami stigma yang tinggi dalam merawat ODS. stigma yang dirasakan keluarga merupakan beban yang mengganggu keluarga. Dari hasil penelitian didapatkan bahwa sebagian besar anggota keluarga yang berperan sebagai keluarga yang merawat ODS memiliki stigma yang tinggi dalam merawat ODS. Keluarga yang merasakan stigma yang tinggi akan menghindari dan menyembunyikan hubungan dengan ODS ${ }^{35}$. Stigma yang tinggi yang dirasakan keluarga akan berdampak pada peninggakatan beban keluarga, meningkatkan stress yang berpengaruh terhadap kualitas hidup dan depresi ${ }^{36}$.

\section{SIMPULAN DAN SARAN}

Berdasarkan penelitian yang dilakukan di wilayah kerja Puskesmas Nanggalo Kota Padang tentang hubungan pengetahuan, stigma pada keluarga terhadap beban keluarga dalam merawat pasien skizorenia dengan jumlah sampe 87 orang. Sehingga dapat disimpulkan : Keluarga yang merawat ODS di wilayah kerja Puskesmas Nanggalo Kota Padang memiliki beban yang berat sebanyak 52 orang $(59,8 \%)$.Keluarga yang merawat ODS di wilayah kerja Puskesmas Nanggalo Kota Padang memiliki tingkat pengetahuan rendah sebanyak 50 orang $(57,5 \%)$.Keluarga yang merawat ODS di wiayah kerja Puskesmas Nanggalo Kota Padang memiliki stigma yang tinggi sebanyak 46 orang $(52,9 \%)$ keluarga.Terdapat hubungan yang bermakna antara stigma pada keluarga dengan beban keluarga dalam merawat ODS di wilayah kerja Puskesmas Nanggalo Kota Padang.Tidak terdapat hubungan yang bermakna antara tingkat pengetahuan keluarga dalam ODS dengan beban keluarga di wilayah kerja Puskesmas Nanggalo Kota Padang

Disarankan kepada tenaga kesehatan khususnya perawat Jiwa komunitas dapat dijadikan masukan dalam membantu dalam program mengurangi stigma pada keluarga dengan memberikan pendidikan kesehatan kepada masyarakat mengenai penyakit skizofrenia. 


\section{DAFTAR PUSTAKA}

1. Stuart GW. Principles and Practice: Psychiatric Nursing. (9th Edition). 9th ed. (9th, ed.). Mosby Elsevier: St. Louis: Mosby Elsevie; 2019.

2. Velázquez-brizuela IE, Ortiz GG, Ventura-castro L, Árias-merino ED, Pacheco-moisés FP, Macías-islas MA. Prevalence of Dementia , Emotional State and Physical Performance among Older Adults in the Metropolitan Area of Guadalajara , Jalisco , Mexico. 2014;2014.

3. WHO. Skizofrenia. 4 oktober 2019.

4. Riskesdas. Hasil Utama Riskesdas Tentang Prevalensi Diabetes Mellitus di Indonesia 2018. Has Utama Riskesdas Tentang Prevalensi Diabetes Melitus di Indones 2018. 2018. doi:1 Desember 2013

5. Riskesdas. RISET KESEHATAN DASAR. Riskesdas. 2018:198.

6. Stuart GW. Prinsip Dan Praktik KEPERAWATAN KESEHATAN JIWA STUART. Singaore: Elsevier; 2016.

7. Gangrade A. The Effect of Music on the Production of Neurotransmitters, Hormones, Cytokines, and Peptides A Review. 2015;(May). doi:10.1177/1943862111415117

8. Putri VS, Mustikasari M, Renidayati R. Pengalaman Keluarga Merawat Pasien Halusinasi Pendengaran di Rumah Sakit Jiwa Jambi. J IIm Univ Batanghari Jambi. 2019;19(3):497. doi:10.33087/jiubj.v19i3.717

9. Freska W, Putit Z, Dayati R. The parents experience in caring children with learning difficulties in children and adolescent Polyclinic at HB Sa'anin Psychiatry HospitalPadang Year 2015. Elev Int J Nurs Educ Pract Res. 2018;1(1):12-15. doi:10.25077/elevate.1.1.12-15.2018

10. Susilowati S, Wihastuti TA, Supriati L. Faktor Yang Berhubungan Dengan Dukungan Keluarga Dalam Merawat Pasien Skizofrenia. Journals Ners Community. 2016;7(1):114. http://journal.unigres.ac.id/index.php/JNC/article/view/108/106.

11. Niu B, Zhang L. The Burden of Mental Illness and Mental Distress on Family Members. J Ment Health Policy Econ. 2020;23(1):3-17.

12. Gusdiansyah E. Hubungan dukungan dan beban keluarga dengan tingkatan skizofrenia. J Kesehat Lentera 'Aisyiyah. 2018;1(1):41-54.

13. Zahra RF, Sutejo S. Hubungan dukungan instrumental dengan beban pada anggota keluarga skizofrenia di Poliklinik Keperawatan Jiwa RSJ Grhasia Provinsi DIY. Caring J Keperawatan. 2019;8(1):9-14. doi:10.29238/caring.v8i1.362

14. Damaiyanti S. PENGARUH TERAPI PSIKOEDUKASI TERHADAP BEBAN SOLOK TAHUN 2017 . Siska Damaiyanti Program Pasca Sarjana Keperawatan Jiwa Universitas Andalas. 2018;XII(8):158-166. 
15. National Institute for Health and Care Excellence. NICE guideline [NG32]. Older people: Independence and mental wellbeing. 2015;(December 2015).

16. Marquez AR. Family Caregivers' Monitoring of Medication Usage: A Qualitative Study of Mexican-Origin Families with Serious Mental Illness. Cult Med Psychiatry 35. 2011. doi:https://link.springer.com/article/10.1007\%2Fs11013-010-9198-3

17. Pérez JJN, Marqués ÁC. Family burden, social support and community health in caregivers of people with serious mental disorder. Rev da Esc Enferm da USP. 2018;52:e03351-e03351. doi:10.1590/s1980-220x2017029403351

18. Friedman MM. Buku Ajar Keperawatan Keluarga. 5th ed. jakarta; 2010.

19. Erwanto R. Faktor yang Berhubungan dengan Beban Keluarga dalam Merawat Aktifitas Sehari-hari pada Lansia. J Ners dan Kebidanan Indones. 2017;4(3):117. doi:10.21927/jnki.2016.4(3).117-122

20. Safitri R. FAKTOR- FAKTOR YANG BERHUBUNGAN DENGAN STIGMA MASYARAKAT TERHADAP ORANG DENGAN GANGGUAN JIWA DIKELURAHAN PASA GADANG WILAYAH KERJA PUSKESMAS PEMANCUNGAN PADANG SELATAN TAHUN 2018. 2019.

21. Yusnipah Y. Tingkat Pengetahun Keluarga Dalam Merawat Dalam Merawat Pasien Halusinasi di Poloklinik Psikiatri Rumah Sakit Marzuki Mahdi Bogor. 2012.

22. Ar-Rasily O, Dewi P. Faktor - Faktor Yang Mempengaruhi Tingkat Pengetahuan Orang Tua Mengenai Kelainan Genetik Penyebab Disabilitas Intelektual Di Kota Semarang. Diponegoro Med J (Jurnal Kedokt Diponegoro). 2016;5(4):1422-1433.

23. Candra LIAWi, Kartika HY. Proses penerimaan anggota keluarga orang dengan skizofrenia. J Psikol Udayana. 2019:89-102.

24. Amri LF. Efektifitas Edukasi Pada Caregiver Tentang Pengetahuan Kejadian Pengabaian Lansia Effectiveness of Education on Knowledge About The Event Negligence Caregiver Elderly. 3(2):130-139.

25. Sasra A. HUBUNGAN STIGMA GANGGUAN JIWA DENGAN PERILAKU MASYARAKAT PADA ORANG DENGAN GANGGUAN JIWA DI JORONG SURAU KUBUAJ KANAGARIAN TIGO BALAI KECAMATAN MATUR KABUPATEN AGAM. Russ J Econ. 2018;48(2):123-154.

26. Anggreni NWY, Herdiyanto YK. Pengaruh Stigma Terhadap Self Esteem Pada Remaja Perempuan Yang Mengikuti Ektrakurikuler Tari Bali Di Sman 2 Denpasar. J Psikol Udayana. 2017;4(1):208-221. doi:10.24843/jpu.2017.v04.i01.p20

27. Larson JE, Corrigan P. The stigma of families with mental illness. Acad Psychiatry. 2018;32(2):87-91. doi:10.1176/appi.ap.32.2.87

28. Alfiandi R, Jannah SR, Tahlil T, et al. Analisis Faktor-Faktor yang Mempengaruhi 
Beban Keluarga dalam Merawat Klien Gangguan Jiwa di Kabupaten Aceh Besar Analysis of Influencing Factors of Family Burden in Caring for Clients with Mental Disorders in Aceh Besar District Perhatian terhadap masala. 2018.

29. Reknoningsih W, Daulima NHC, Putri YSE. Pengalaman Keluarga dalam Merawat Pasien Pascapasung. J Keperawatan Indones. 2015;18(3):171-180. doi:10.7454/jki.v18i3.421

30. SUILIA R. HUBUNGAN DUKUNGAN KELUARGA DENGAN BEBAN KELURGA DALAM MERAWAT PASIEN SKIZOFRENIA. J Chem Inf Model. 2019;53(9):16891699.

31. Rahmi D. HUBUNGAN PENGETAHUAN DENGAN SIKAP KELUARGA MERAWAT KLIEN DALAM MENGENDALIKAN HALUSINASI DI UNIT POLIKLINIK JIWA A (UPJA) RSJ. PROF. HB. SA'ANIN PADANG. 2018;XII(8):79-88.

32. Mulyana S, Mariyati, Kustriyani M. Hubungan Stigma Masyarakat Dengan Beban Keluarga Yang Memiliki Anak Retardasi Mental Di Slb Negeri Semarang. Semin Nas Widya Husada 1 "Strategi dan Peran SDM Kesehat dalam Meningkat Derajat Kesehat di Era Revolusi Ind 40.” 2014;6:6-13.

33. Ayalew M, Workicho A, Tesfaye E, Hailesilasie H, Abera M. Burden among caregivers of people with mental illness at Jimma University Medical Center, Southwest Ethiopia: a cross-sectional study. Ann Gen Psychiatry. 2019;18(1):1-11. doi:10.1186/s12991019-0233-7

34. Nasriati R. Stigma Dan Dukungan Keluarga Dalam Merawat Orang Dengan Gangguan Jiwa (ODGJ). J IIm IImu - IImu Kesehat. 2017;15(1):56-65.

35. Sandy M. Magaña at. all. Psychological Distress Among Latino Family Caregivers of Adults With Schizophrenia: The Roles of Burden and Stigma Sandy. Bone. 2008;23(1):1-7.

36. Yin Y, Zhang W, Hu Z, et al. Experiences of stigma and discrimination among caregivers of persons with schizophrenia in China: A field survey. PLoS One. 2014;9(9). doi:10.1371/journal.pone.0108527 